\title{
PENGARUH BAURAN PEMASARAN JASA TERHADAP KEPUTUSAN MAHASISWA PERANTAU MEMILIH WARUNG MAKAN DI KELURAHAN TONDO KOTA PALU
}

\author{
Jubaeda \\ Suardi \\ Nirwan \\ Program Studi S1 Manajemen, Fakultas Ekonomi, Universitas Tadulako \\ Email: edaedacun@gmail.com
}

\begin{abstract}
the purpose of this study was to determine 1) the effect of the marketing mix consisting of products, prices, places, promotions, people, processes, and physical evidence on student decisions 2) the effect of products on student decisions. 3) the effect of prices on student decisions. 4) the influence of place on student decisions. 5) the effect of promotion on student decisions. 6) the influence of people on student decisions. 7) the effect of the process on student decisions. 8) the effect of physical evidence on students. this type of research is descriptive research. the number of samples was 80 respondents using accidental sampling technique. the method of analysis is Multiple Linear Regression. research results 1) Marketing mix variables consisting of products, prices, places, promotions, people, processes, and physical evidence simultaneously have a significant effect on student decisions. 2) product variables significantly influence student decisions. 3) the variable price has a significant effect on student decisions. 4) promotion variables significantly influence student decisions. 5) place variables significantly influence student decisions. 6) the variable of people has a significant effect on student decisions. 7) process variables have a significant effect on student decisions. 8) physical evidence variables significantly influence student decisions.

Keywords: Marketing Mix, Product, Price, Place, People, Process, Physical Proof.
\end{abstract}

\begin{abstract}
Abstrak
Tujuan penelitian adalah untuk mengetahui 1) pengaruh bauran pemasaran yang terdiri dari produk, harga, tempat, promosi, orang, proses, dan bukti fisik terhadap keputusan mahasiswa. 2) pengaruh produk terhadap keputusan mahasiswa. 3) pengaruh harga terhadap keputusan mahasiswa. 4) pengaruh variabel tempat terhadap keputusan mahasiswa. 5) pengaruh promosi terhadap keputusan mahasiswa. 6) pengaruh orang terhadap keputusan mahasiswa. 7) pengaruh proses keputusan mahasiswa. 8) pengaruh bukti fisik terhadap keputusan mahasiswa. Tipe penelitian ini merupakan penelitian deskriptif. Jumlah sampel 80 responden dengan menggunakan teknik aksidental sampling, metode analisis adalah regresi linear berganda. Hasil penelitian 1) variabel bauran pemasaran yang terdiri dari produk, harga, tempat, promosi, orang, proses, dan bukti fisik secara serempak berpengaruh signifikan terhadap keputusan mahasiswa. 2) variabel produk berpengaruh signifikan terhadap keputusan mahasiswa. 3) variabel harga berpengaruh signifikan terhadap keputusan mahasiswa. 4) variabel tempat berpengaruh signifikan terhadap keputusan mahasiswa. 5) variabel promosi berpengaruh signifikan terhadap keputusan mahasiswa. 6) variabel orang berpengaruh signifikan terhadap keputusan mahasiswa. 7) variabel proses berpengaruh signifikan terhadap keputusan mahasiswa. 8) variabel bukti fisik terhadap keputusan mahasiswa.

Kata Kunci: Bauran pemasaran, produk, Harga, Tempat, Promosi, Orang, Proses, Bukti Fisik, Keputusan Mahasiswa.

\section{PENDAHULUAN}

Usaha kecil merupakan bagian integral dari dunia usaha nasional yang mempunyai kedudukan, potensi dan peranan yang sangat strategis dalam mewujudkan tujuan pembangunan nasional. Dengan usaha yang ada sekarang ini sudah terbilang banyak dan beraneka ragam usaha yang berkembang,
\end{abstract}


jumlah penduduk yang terus bertambah, perekonomian yang semakin sulit dan lapangan kerja yang peluangnya semakin sedikit, membuat penduduk semakin banyak pengangguran. Setiap usaha baik yang bergerak di bidang jasa maupun barang dituntut untuk meningkatkan kinerja pelayanannya agar dapat memberikan kepuasan kepada setiap konsumen, serta kualitas jasa atau barang yang ditawarkan bisa bersaing dengan usaha lain tetap dapat bertahan ditengah banyaknya pesaing. Seiring dengan perkembangan zaman, usaha makanan di indonesia cukup menyajikan dan bervarian. Sangat banyak makanan yang diproduksi, baik dalam produksi skala kecil seperti industri rumahan (home indutry) maupun skala besar seperti pabrik. Salah satu konsep yang dijadikan sebagai alat untuk menciptakan competitive advantage oleh suatu perusahaan adalah bauran pemasaran marketing mix. (Sumarmi dan Soeprihanto, 2010:274). Bauran pemasaran adalah kombinasi dari variabel atau kegiatan yang merupakan inti dari sistem pemasaran. Produk yang ditawarkan oleh warung makan dapat menjadi salah satu jenis berbagai macam menu yang didapatkan mahasiswa perantau untuk memenuhi kebutuhan sehari-hari. Harga merupakan sejumlah uang yang ditukar dengan produk yang terdapat pada menu suatu restoran atau warung makan tersebut. Tempat mengingat mudahnya akses jalan untuk mencapai lokasi warung makan sehingga mahasiswa perantau bisa dengan mudah untuk mendapatkan warung makan di kelurahan tondo. Promosi merupakan dimana warung makan harus mampu mempromosikan warung makan tersebut disalah satu kalangan masyarakat Kota Palu, maupun informasi melalui spanduk, serta nformasi dari teman, agar mahasiswa dapat lebih mengenal warung makan.

\section{KAJIAN LITERATURE DAN PENGEMBANGAN HIPOTESIS}

Buchari (2014:1) mendefenisikan bahwa kita memasarkan tidak berarti orang menawarkan harga barang tetapi lebih dari macam cara dalam kegiatan membeli. Menurut Abdullah (2014:2) mendefenisika suatu pemasara dari berbagai kegiatan bisnis yang dipikirkan untuk menentukan harga barang yang dapat memuaskan keinginan untuk membeli. Menurut Stanton (dalam Swasta dan Hadoko1997:3) mendefenisikan pemasar sebagai kegiatan yang ditujukan untuk memperkenalkan barang kepada konsumen.

\section{Pemasaran management}

Menurut Alma (2004:130) menyatakan bahwa manajemen pemasaran adalah merencanakan, pengarahan dan pengawasan seluruh kegiatan pemasaran ataupun bagian dipemasaran. Sedangkan Lupiyodi (2006:6) mengatakan pemasara sebagai suatu perencanaang sertah yang diinginkan. Defenisi tersebut mecakup serta menumbukan pelanggabn kegiatan atau tujuan organisasi agar bisa tercapai.

\section{Pemasaran Bauran}

Bauran pemasaran yang dikemukakan Kotler \& Amstrong (2008:76) bahwa bauran pemasaran yang terdiri dari tujuh bauran termasuk orag proses plomosi produ bukti fisik. Selanjutnya Sumarmi dan Soeprihanto (2010:274) mendefenisika pemasaran yang merupakansistem dari pemasarang dengan kumpula variabel yang digunakan oleh perusahaan utuk memegaruhi kosumen.

\section{Produk}

Produk dapat dikatakan untuk mendapatkan perhatian dalam membeli serta dapat memuaskan keiginan konsumen. Selanjunya Kotler (2000:451) berpedapat bahwa produk juga dapat dikatakan segala sesuatu yang dapat ditawarkan oleh pihak warung makan terhadap mahasiswa ataau pengunjung untuuk memeperkenalkaan diperhatiikan serta apa 
yang dimiliki dandigunakang dalam mengonsumsi sehingga dapat memuaskan keinginann mahasiswa untuk kebuthaan mereka.

\section{Harga}

Harga dapa dikataakan nilai tukar degan uang untuk manfaat yang diperoleh dari barangmaupun jasa bagi waktu tertentu. Kotler dan Keller (2012:25) mendefenisikan harga sebagai jumlah uang atauu nilai tukar untuk menghasilka keutungan terhadap produ. Harga juga terdapt hasil penjuala dari pihak warung makan.

\section{Tempat}

Tempat (place) merupakan hal peting dalam kebijaksanaa distribusi perusahaann harus mengidentifikasi menarik dan menghubungkan berbagai pemasara untu menawarkan produk layanannya secara efesien dan efektif pada pasar sasaran. Tempat dapat dikatakan sebagai suatu strategi yang yang ditentukan oleh pihak warung makan dan bagaimana orang tersebut dapat menjual suatu jenis makanan atau Hal yang lain.ole karna itu bagaimana orag itu mampuh utuk menetapakan lokai serata distribusor mahasiswa atau warug makang tersebut.

\section{Promosi(Promotion)}

Semakin ketatnya persaingan dalam dunia usaha, menuntut pihak manajemen pengelola usaha untuk mengambil langkah-langkah strategis guna memperkenalkan produknya kemasyarakat luas. Promosi merupakan langkah yang sangat tepat untuk memperkenalkan profil produk dengan semua keunggulannya untuk memikat/menarik perhatian konsumen.

\section{Orang (People)}

Orang disini sebagaimana sumber daya manusia ouput yang diterima oleh kionsumen dalam mencapai standar yang ditetpkan rekrutme yang penting. Sedangkan menurut Tjiptono (dalam Sunyoto, 2012:238), mendefenisikan sebagian besar orang dalam bentu baurang pemasaran. maka people yang berfungsi sebagai providor untu mempengaruhi kualitas yang diberikan.

\section{Proses (Process)}

Proses sebagai faktor penting dalam konsumen untuk berperang sebagai pelangga mahasiswa mauapun warung makang hal ini dapat berpengaruh oleh sebuah warung makan terhadap pelangganya.Selanjutnya menurut Tjiptono (dalam Sunyoto, 2012:23), menyatakan bahwa proses merupakan gabungan semua aktivitas, umumnya terdiri dari prosedur, jadwal pekerjaan, mekanisme, aktivitas dan hal-hal rutin, dimana jasa dihasilkan dan disampaikan kepada konsumen.

\section{Bukti Fisik (Phisical Evident)}

Phisikal evidet merupakan suatu jasa yang menyebabkan resiko dalam kepurtusang pembelian yang semakin besar. Selanjutnya menurut Tjiptono (dalam Sunyoto, 2012:239), menyatakan bahwa salah satu unsur penting dalam baurang pemasaran utuk mengurangi tingkat resiko. Costumer dapat dilihat salah satu bagian distribusi dimana pelayanang diberikan kepada mahasiswa terhadap kepuasan yang diberikan oleh pihak warung makang.

\section{Perilaku Konsumen}

Sunyoto (2012:255) mengatakan konsumen sebagai kegiatan seeseorang yang mendapatkan untuk mempergunskan produk dalam proses pemgambilan keputusan. Menurut Sunyoto (2013:1) mendefenisikan bahwa ada beberapa hal pentig yang dilakukan oleh 
perilaku konsumeg dalam bentuk merancang atau membentuk keputusan yang bijak untuk mengetahui suatu yang merencanakan harga.

\section{Proses Pengambilan Keputusan}

Menurut tujuan pembelian, konsumen dapat dikelompokkan menjadi konsumen akhir (individual), yang terdiri atas individu dan rumah tangga yang tujuan pembeliannya adalah untuk memenuhi kebutuhan sendiri atau konsumsi. Sedangkan kelompok lain adalah konsumen organisasional yang terdiri atas organisasi, pemakai industri, pedagang dan lembaga nonprofit yang tujuan pembeliannya adalah untuk memperoleh laba atau untuk memenuhi kebutuhan dan kesejahteraan anggotanya (Suryani, 2013:13).

\section{METODE PENELITIAN}

Jenis penelitian ini adalah deskriptif kausal dan data yang diperoleh dianalisis secara kuantitatif. Metode penelitian kuantitatif dapat diartikan sebagai metode penelitian yang berlandaskan pada filsafat positivisme, digunakan untuk meneliti pada populasi atau sampel tertentu, teknik pengambilan sampel pada umumnya dilakukan secara random, pengumpulan data menggunakan instrumen penelitian, analisis data bersifat kuantitatif/statistik dengan tujuan menguji hipotesis yang telah ditetapkan ( Sugiyono 2015:11).

Lokasi untuk penelitian dilakukan di warung mas bambang Jl. Padat Karya Kota Palu. Jenis data kuantitatif yang digunakan yaitu data responden, uji instrumen penelitian, uji asumsi klasik dan metode analisis untuk membuktikan hubungan dan pengaruh antar variabel bebas dan terikat. Menggunakan skala nominal dan ordinal. Data kualitatif yang digunakan adalah dokumentasi dan sejarah. Data primer yang diambil pada penelitian ini adalah data karakteristik responden (jenis kelamin, usia, pendidikan mahasiswa yang memilih warung makan di kelurahan tondo Kota Palu, dan frekuensi mahasiswa perantau yang sudah berkunjung pada warung makan mas bambang dan jawaban responden. Sumber data sekunder dalam penelitian ini yaitu sejarah singkat warung makan di Kota Palu, data yang telah disediakan oleh warung makan di Kota Palu, dan jurnal.

Populasi dalam penelitian ini adalah seluruh mahasiswa perantau yang memilih warung makan di kelurahan tondo Kota Palu akan tetapi sudah mengetahui melalui spanduk, mendapatkan informasi dari mulut ke mulut tentang warung makan, karena tidak ada data yang menunjukkan batas jumlah populasi tentang hal tersebut, maka populasi dalam penelitian ini jumlahnya tidak diketahui atau non probability sampling.

Teknik penarikan sampel yang digunakan adalah teknik aksidental sampling dimana peneliti memilih sampel berdasarkan penilaian terhadap beberapa karakteristik anggota sampel yang disesuaikan dengan maksud peneliti merujuk pada pendekatan dari Roscoe (dalam Sugiyono 2014:130). Untuk menentukan jumlah atau besaran sampel, maka peneliti merujuk pada Sugiyono (2014) yang mengatakan bahwa untuk penelitian multivariate (korelasi atau regresi ganda) maka jumlah sampel yang ideal adalah minimal 10 kali variabel (independen dan dependen). Berdasarkan teori tersebut maka jumlah sampel dalam penelitian ini ditetapkan dengan ketentuan 10X 8 variabel sama dengan 80 responden. 


\section{HASIL}

Tabel 3. Hasil Uji Analisis Regresi Linear Berganda

\begin{tabular}{|c|c|c|c|}
\hline \multirow{2}{*}{$\begin{array}{c}\text { Variabel } \\
\text { Independen }\end{array}$} & $\begin{array}{c}\text { Unstandardized } \\
\text { Coefficients }\end{array}$ & $\begin{array}{l}\text { Standardized } \\
\text { Coefficients }\end{array}$ & Sig-t \\
\hline & $\mathrm{B}$ & Beta & \\
\hline (Constant) & -3.861 & & 0.059 \\
\hline Produk (X1) & 0.240 & 0.316 & 0.001 \\
\hline Harga (X2) & 0.111 & 0.191 & 0.034 \\
\hline Tempat (X3) & 0.143 & 0.202 & 0.038 \\
\hline Promosi (X4) & 0.155 & 0.189 & 0.035 \\
\hline Orang (5) & 0.123 & 0.202 & 0.038 \\
\hline Proses (X6) & 0.268 & 0.188 & 0.040 \\
\hline Bukti Fisik (X7) & 0.129 & 0.213 & 0.027 \\
\hline \multicolumn{2}{|l|}{$\begin{array}{ll}\text { Adjusted R Square } & =0.477 \\
\text { R-Squared }\left(\mathrm{R}^{2}\right) & =0.523 \\
\text { Multiple R } & =0.723\end{array}$} & Sig F $=0.0$ & \\
\hline
\end{tabular}

Sumber: Data Diolah

Model persamaan regresi linier berganda dalam penelitian ini adalah:

$Y=-3,861+0,240 X_{1}+0,111 X_{2}+0,143 X_{3}+0,115 X_{4}+0,123 X_{5}+X_{5} 0,268 X_{6}+0,129 X_{7}$

Koefisien regresi dalam model persamaan diatas di jelaskan berikut ini:

Untuk mengetahui pengaruh signifikan secara simultan maupun secara parsial dari variabel independen yakni variabel produk $\left(\mathrm{X}_{1}\right)$, variabel harga $\left(\mathrm{X}_{2}\right)$, variabel promosi $\left(\mathrm{X}_{3}\right)$, variabel tempat $\left(\mathrm{X}_{4}\right)$, Variabel orang $\left(\mathrm{X}_{5}\right)$, variabel proses $\left(\mathrm{X}_{6}\right)$, variabel bukti fisisk $\left(\mathrm{X}_{7}\right)$, secara serempak berpengaruh signifikan terhadap variabel dependen yakni keputusan mahasiswa (Y) mahasiswa memilih warung makan di kelurahan tondo Kota Palu. Berdasarkan hasil tersebut digunakan uji F dan uji t. Penjelasan lebih lengkapnya akan dijelaskan dibawah:

a. Variabel produk $\left(\mathrm{X}_{1}\right)$, hasil perhitungan diperoleh nilai sig t sebesar $0.001<\alpha=0,05$, artinya bahwa secara parsial variabel produk berpengaruh secara nyata (signifikan) terhadap keputusan mahasiswa perantau memilih warung makan di kelurahan tondo Kota Palu, dengan kata lain hipotesis kedua yang diajukan dapat diterima kebenarannya.

b. Variabel harga $\left(\mathrm{X}_{2}\right)$, hasil perhitungan di peroleh nilai sig t $0.034<\alpha=0,05$, artinya bahwa secara parsial variabel harga berpengaruh secara nyata (signifikan) terhadap keputusan mahasiswa perantau memilih warung makan di kelurahan tondo Kota Palu, dengan kata lain hipotesis ketiga yang diajukan dapat diterima kebenarannya.

c. Variabel tempat $\left(\mathrm{X}_{3}\right)$, hasil perhitungan diperoleh nilai sig t sebesar $0.038<\alpha=0,05$, artinya bahwa secara parsial variabel tempat berpengaruh secara nyata (signifikan) terhadap keputusan mahasiswa perantau memilih warung makan di kelurahan tondo Kota Palu, dengan kata lain hipotesis ketiga dapat diterima kebenarannya.

d. Variabel promosi $\left(\mathrm{X}_{4}\right)$, hasil perhitungan diperoleh nilai sig t sebesar $0.035<\alpha=0,05$, artinya bahwa secara parsial variabel promosi berpengaruh secara nyata (signifikan) terhadap keputusan mahasiswa perantau memilih warung makan di kelurahan tondo Kota Palu, dengan kata lain hipotesis keempat dapat diterima kebenarannya. 
e. Variabel orang $\left(\mathrm{X}_{5}\right)$, hasil perhitungan diperoleh nilai sig t sebesar $0,038<\alpha=0,05$, artinya bahwa secara parsial variabel orang berpengaruh secara nyata (signifikan) terhadap keputusan mahasiswa perantau memilih warung makan di kelurahan tondo Kota Palu, dengan kata lain hipotesis kelima dapat diterima kebenarannya.

f. Variabel proses $\left(\mathrm{X}_{6}\right)$, hasil perhitungan diperoleh nilai sig t sebesar $0.040<\alpha=0,05$, artinya bahwa secara parsial variabel proses berpengaruh secara nyata (signifikan) terhadap keputusan mahasiswa perantau memilih warung makan di kelurahan tondo Kota Palu, dengan kata lain hipotesis keenam dapat diterima kebenarannya.

g. Bukti fisik $\left(\mathrm{X}_{7}\right)$, hasil perhitungan diperoleh nilai sig t $0.027<\alpha=0,05$, artinya bahwa secara parsial variabel bukti fisik berpengaruh secara nyata (signifikan) terhadap keputusan mahasiswa perantau memilih warung makan di kelurahan tondo Kota Palu, dengan kata lain hipotesis ketujuh dapat diterima kebenarannya.

\section{PEMBAHASAN}

1. Pengaruh variabel produk $\left(\mathrm{X}_{1}\right)$, memberikan pengaruh positif dan signifikan terhadap keputusan mahasiswa perantau memilih warung makan di kelurahan tondo kota palu (Y). Artinya mahasiswa tertarik mengunjungi warung makan di kelurahan tondo Kota Palu karena rasa makanannya lebih enak, higienis, menunya bervariasi, dan ketersediaan produk makanan yang ditawarkan. Warung makan di kelurahan tondo Kota Palu mengutamakan penyajian produk yang higienis dan cita rasa masakan yang disukai oleh konsumen. Kualitas produk dapat dilihat dari bahan baku yang digunakan, penyajian yang dilakukan dan atribut yang ada pada produk tersebut seperti rasa, aroma, bentuk, dan penampilan produk. Warung makan di kelurahan tondo Kota Palu memiliki standar tersendiri dalam penyediaan bahan baku, hal ini bertujuan untuk menjaga kualitas produk yang dihasilkan.

2. Pengaruh variabel harga $\left(\mathrm{X}_{2}\right)$, memberikan pengaruh positif dan signifikan terhadap keputusan mahasiswa perantau memilih warung makan di kelurahan tondo Kota Palu (Y). Artinya, adanya pengaruh harga menunjukan bahwa umumnya mahasiswa tertarik mengunjungi warung makan di kelurahan tondo Kota Palu karena menilai harga makanan di warung makan lebih murah, terjangkau, dan bersaing dari warung makan ataupun rumah makan lainnya. Harga memainkan bagian yang sangat penting dalam bauran pemasaran, karena penetapan harga memberikan penghasilan bagi usaha warung makan, sedangkan elemen-elemen lainnya menimbulkan harga. Dari sini, maka dapat dikatakan bahwa mahasiswa akan berselera membeli suatu barang atau jasa tersebut. Keadaan ini harus dipertahankan oleh warung makan di kelurahan tondo Kota Palu karena dinilai sangat pengaruh pada kunjungan mahasiswa dimana image harga yang melekat pada warung makan tersebut tentu dari segi pemasaran memberikan keuntungan. Dengan jumlah yang terus kunjungan yang terus meningkat, maka warung makan di kelurahan tondo Kota Palu dapat meningkatkan volume penjualan, pendapatan, dan perolehan labadari pengelolaan usahanya ditengah kempotetifnya persaingan usaha yang ada.

3. Pengaruh variabel tempat $\left(\mathrm{X}_{3}\right)$, memberikan pengaruh positif dan signifikan terhadap keputusan mahasiswa perantau memilih warung makan di kelurahan tondo Kota Palu (Y). Artinya mahasiswa tertarik mengunjungi warung makan di kelurahan tondo Kota Palu karena lokasinya dapat dijangkau, tempat parkir cukup memadai, fasilitas warung makan cukup memadai, dekat dengan kos-kosan mahasiswa. Akan tetapi, dari keempat indikator tempat ini, tempat parkir yang harus diperhatikan oleh pemilik warung makan karena area parkir lebih dekat dengan jalan raya serta kurang luas sehingga sering menimbulkan kemacetan lalulintas. Keadaan ini harus perlu dirubah dengan menyediakan lahan/area parkir yang lebih luas, karena akan mempengaruhi persepsi 


\section{JMUT}

Vol. 6, No.2. Mei 2020, 121-129

konsumen untuk berkunjung. Oleh karena itu, indikator tersebut harus di perhatikan dan diperbaiki karena dari segi pemasaran dinilai mampu meningkatkan intensitas kunjungan masyarakat pada warung makan di kelurahan tondo Kota Palu.

4. Pengaruh variabel promosi $\left(\mathrm{X}_{4}\right)$, memberikan pengaruh positif dan signifikan terhadap keputusan mahasiswa perantau memilih warung makan di kelurahan tondo Kota Palu (Y). Artinya, mahasiswa tertarik mengunjungi warung makan di kelurahan tondo Kota Palu karena indikator informasi dari teman, melalui brosur, atau papan nama yang menarik mahasiswa untuk datang berkunjung memillih warung makan di kelurahan tondo Kota Palu. Kegiatan promosi merupakan salah satu bauran pemasaran yang digunakan oleh perusahaan untuk mengadakan komunikasi dengan pasarnya, karena dengan adanya promosi, maka mahasiswa akan mengetahui hadirnya suatu produk. Promosi merupakan suatu bentuk komunikasi pemasaran yang berusaha untuk menyebarkan informasi, mempengaruhi dan membujuk, mengingatkan pasar sasaran atas perusahaan dan produknya agar bersedia menerima, membeli, dan loyal pada produk yang ditawarkan perusahaan yang bersangkutan.

5. Variabel orang $\left(\mathrm{X}_{5}\right)$, memberikan pengaruh positif dan signifikan terhadap keputusan mahasiswa perantau memilih warung makan di kelurahan tondo Kota Palu (Y). Artinya, mahasiswa tertarik mengunjungi warung makan di kelurahan tondo Kota Palu karena keramahan karyawan, pelayanan yang cepat, kejujuran karyawan, dan kesopanan karyawan dalam melayani konsumen. Dalam hubungannya dengan pemasaran, maka orang yang berfungsi sebagai penyedia jasa karena sangat mempengaruhi kualitas jasa yang diberikan kepada konsumen ketika memilih berkunjung ke warung makan di kelurahan tondo Kota Palu. Untuk mencapai kualitas pelayanan yang baik, diperlukan pelayanan karyawan yang jujur, ramah, sopan, dan cepat dalam melayani konsumen sehingga karyawan mampu memberikan kepuasan kepada konsumen. Dari segi pemasaran, kegiatan orang/karyawan akan memberikan pengaruh positif terhadap peningkatan volume penjualan, pendapatan, perolehan laba, dan kontinuitas kelangsungan hidup dalam pengelolaan usaha warung makan di kelurahan tondo Kota Palu ditengah kompetitifnya persaingan usaha.

6. Pengaruh variabel proses $\left(\mathrm{X}_{6}\right)$, memberikan pengaruh positif dan signifikan tarhadap keputusan mahasiswa perantau memilih warung makan di kelurahan tondo Kota Palu (Y). Artinya, mahasiswa tertarik mengunjungi warung makan di kelurahan tondo Kota Palu karena kecepatan dalam pelayanan dan mengantar pesanan. Berdasarkan hasil tersebut pemilik warung makan di kelurahan tondo Kota Palu lebih meningkatkan, memperhatikan keramahan dan kecepatan pada saat melayani pelanggan yang datang, karena indikator tersebut, karena indikator tersebut sangat mempengaruhi persepsi konsumen pada warung makan di kelurahan tondo Kota Palu. Proses pelayanan setiap hari di lakukan secara sistematis mulai dari penerimaan pengunjung sampai pengunjung meninggalkan ruangan rumah makan. Mekanisme penyajian menu makanan dilakukan berdasarkan pesanan konsumen saat it.

7. Pengaruh variabel bukti fisik $\left(\mathrm{X}_{7}\right)$, memberikan pengaruh positif dan signifikan terhadap keputusan mahasiswa perantau memilih warung makan di kelurahan tondo Kota Palu (Y). Artinya, mahasiswa tertarik mengunjungi warung makan di kelurahan tondo Kota Palu karena ruang tunggu nyaman, kerapian karyawan, kebersihan lingkungan warung makan, tata letak ruang yang rapi, dan ketersediaan lahan parkir. Bukti fisik merupakan keputusan yang dibuat oleh pemilik warung makan mengenai desain dan tata letak dari ruang serta bukti pendukung seperti karyawan yang berfungsi sebagai pelengkap/pendukung jasa. Bukti fisik membantu pemilik warung makan untuk memosisikan usahanya di pasar dan memberikan dukungan nyata apalagi yang berhubungan dengan lokasi usaha. Dari segi pemasaran, bukti fisik akan memberikan pengaruh positif terhadap peningkatan volume penjualan, pendapatan, perolehan laba, dan kontinuitas kelangsungan hidup 
dalam pengelolaan usaha warung makan di kelurahan tondo Kota Palu ditengah kompetitifnya persaingan usaha.

\section{KESIMPULAN DAN SARAN}

\section{Kesimpulan}

1. Variabel bauran pemasaran yang terdiri dari produk, harga, tempat, promosi, orang, proses, dan bukti fisik secara serempak berpengaruh signifikan terhadap keputusan mahasiswa perantau memilih warung makan di kelurahan tondo Kota Palu dengan jumlah responden 80 orang di peroleh angka signifikansi sebesar 0,000 atau $<0,05$, maka hipotesis pertama dapat diterima.

2. Variabel produk berpengaruh signifikan terhadap keputusan mahasiswa perantau memilih warung makan di kelurahan tondo Kota Palu dengan jumlah responden 80 orang diperoleh angka signifikansi sebesar 0,00 atau $<0,05$, maka hipotesis kedua dapat diterima.

3. Variabel harga berpengaruh signifikan terhadap keputusan mahasiswa perantau memilih warung makan di kelurahan tondo Kota Palu dengan jumlah responden 80 orang diperoleh angka signifikansi sebesar 0,000 atau <0,05, maka hipotesis ketiga dapat diterima.

4. Variabel tempat berpengaruh signifikan terhadap keputusan mahasiswa perantau memilih warung makan di kelurahan tondo Kota Palu dengan jumlah responden 80 orang diperoleh angka signifikansi sebesar 0,000 atau < 0,05, maka hipotesis keempat dapat diterima.

5. Variabel promosi berpengaruh signifikan terhadap keputusan mahasiswa perantau memilih warung makan di kelurahan tondo Kota Palu dengan jumlah responden 80 orang diperoleh angka signifikansi sebesar 0,00 atau < 0,05, maka hipotesis kelima dapat diterima.

6. Variabel orang berpengaruh signifikan terhadap keputusan mahasiswa perantau memilih warung makan di kelurahan tondo Kota Palu dengan jumlah responden 80 orang diperoleh angka signifikansi sebesar 0,000 atau <0,05, maka hipotesis ke enam dapat diterima.

7. Variabel proses berpengaruh signifikan terhadap keputusan mahasiswa perantau memilih warung makan di kelurahan tondo Kota Palu dengan jumlah responden 80 orang diperoleh angka signifikansi sebesar 0,000 atau <0,05, maka hipotesis ke tujuh dapat diterima.

8. Variabel bukti fisik berpengaruh signifikan terhadap keputusan mahasiswa perantau memilih warung makan di kelurahan tondo Kota Palu dengan jumlah responden 80 orang diperoleh angka 0,000 atau $<0,05$, maka hipotesis ke delapan dapat diterima.

\section{Saran}

Bagi Perusahaan

1. Dalam penelitian ini variabel proses memiliki pengaruh paling kecil terhadap keputusan mahasiswa perantau memilih warung makan di kelurahan tondo Kota Palu meskipun demikian hendaknya pemilik usaha tetap memperhatikan/mempertimbangkan dalam proses pelayanan konsumen.

2. Dalam penelitian ini variabel produk memiliki pengaruh paling tinggi terhadap keputusan mahasiswa perantau memilih warung makan di kelurahan tondo Kota Palu sebaiknya pemilik usaha harus lebih meningkatkan lagi usahanya sehingga dapat menarik lebih banyak pembeli dan dapat bersaing dengan usaha warung makan lainnya.

3. Bagi peneliti selanjutnya yang ingin meneliti atau melanjutkan penelitian ini, disarankan untuk meneruskan atau mengembangkan penelitian ini dengan mencari faktor lain yang dapat mempengaruhi mahasiswa perantau memilih warung makan seperti faktor produk, faktor harga, dan faktor tempat. 


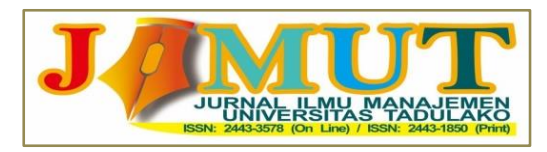

Vol. 6, No.2, Mei 2020, 121-129

\section{REFERENSI}

Abdullah Thamrin, (2014). Manajemen Pemasaran. Francis Tantri, PT. Raja Grafindo Persada, Rajawali Pers, Jakarta.

Alma Buchari, (2014). Manajemen Pemasaran \& Pemasaran Jasa. Alfabeta, Bandung.

Danang Sunyoto, (2013). Perilaku Konsumen Panduan Riset Sederhana Untuk Mengenali Konsumen. Cetakan Pertama, CAPS (Center Of Academic Publishing Service).

Danang Sunyoto, (2012). Konsep Dasar Riset Pemasaran dan Perilaku Konsumen Cetakan 1 Yogyakarta.

Engel James F,et.al (1995). Perilaku Konsumen Edisi Keenam, Jilid 1 Jakarta, Bina Rupa Aksara.

Farhan Gustiyana, (2011). Faktor-faktor yang di Pertimbangkan Konsumen Memilih Cafe Coffe Toffe di Kota Palu.

Fiani S dan Japarianto, (2012). Analisa Pengaruh Food Quality dan Brand Image Terhadap Keputusan Pembelian Roti Kecik Toko Roti Genep's di Kota Solo. E-Jurnal Manajemen Pemasaran. Volume 1. No.1, Hal 1-6.

Hidayat \& Sutupo, (2016). Analisis Pengaruh Persepsi Harga dan Promosi Terhadap Keputusan Pembelian Konsumen Study Kasus pada Warung Spesial Bebek Goreng Andalan. E-Jurnal Of Management. Volume 5. No.3 Hal 1-10.

Ghazali Imam, (2005). Aplikasi Analisis Multivariate Dengan Program SPSS Universitas Diponegoro Semarang.

Hermawan Haris, (2015). Analisis Pengaruh Bauran Terhadap Keputusan, Kepuasan, dan Loyalitas Konsumen Dalam Pembelian Roti Ceria di Jember. E-Jurnal Manajemen Bisnis dan Bisnis Indonesia. Volume 1. No.2.

Hurlock E, (1980). Psikologi Perkembangan Suatu Pendekatan Sepanajang Rentang Kehidupan. Erlangga, Jakarta.

Kotler Philip, \& Keller Kevin Lane, (2009). Manajemen Pemasaran. Edisi Ketiga, Erlangga, Jakarta.

Kotler Philip, (2000). Manajemen Pemasaran Analisis Perencanaan, Pengendalian, Edisi Bahasa Indonesia. Salemba Empat, Jakarta.

Lupiyoadi, (2001). Manajemen Pemasaran. Jasa. Edisi Dua Salemba Empat, Jakarta.

Sugiyono, (2009). Statistika Untuk Penelitian. Alfabeta, Bandung.

Sugiyono, (2014). Metode Penelitian Bisnis. Alfabeta, Bandung.

Tatik Suryani, (2013). Perilaku Konsumen di Era Internet. Edisi Pertama Graha Ilmu, Yogyakarta.

Tukiran Mustafida, (2014). Penelitian Kuantitatif. Alfabeta, Bandung.

Yuliati Uci, (2011). Faktor-Faktor Yang Mempengaruhi Konsumen Dalam Pembelian Makanan Jajan Kue Tradisional di Kota Malang. E-Jurnal Manajemen Bisnis Volume 1. No. Edisi 1 April.

Widiastuti, \& Widiowati, (2014). Faktor-Faktor Yang Mempengaruhi Keputusan Pembelian Pada Warung Makan Mie Jakarta 69. E-Jurnal Ekonomi. Volume 9.No.1 Hal 1-11

S D. (2014). Konsep Dasar Riset Pemasaran dan Perilaku Konsumen (Kedua). Yogyakarta: CAPS (Center for Academic Publishing Service). 